\title{
Threatened Identities and Gendered Opportunities: Somali Migration to America
}

$R$

ecent literature pays close attention to the ways in which gender mediates the migration experience. In addition to showing that gender matters in the migration process, this scholarship highlights how institutions in the host society can provide opportunities to challenge gender hierarchies within migrant households and communities. At the same time, this body of recent works complicates prior assumptions that migration is always empowering for women, by stressing how the empowermentdisempowerment dichotomy simplifies complex processes that both enable women to challenge patriarchal practices and deter them from doing so. This article seeks to extend this literature through an ethnographic investigation of the dynamic process of change in gender relations among Somali immigrants in Minnesota, a Muslim African refugee population. Most immigrant case studies draw from groups originating from Latin America and Asia, the major sources of migration to the United States in recent decades. Focusing on the migration experiences of Somalis offers a fresh venue to further document and theorize the gendered nature of the new wave of twenty-first-century migration.

The complete collapse of the Somali state in 1991 led to mass migration to the United States, and that migration continues today. As with the Southeast Asian refugee influx of the 1970s and 1980s, tens of thousands of Somali refugees with limited human capital escaped from protracted refugee camps in northeastern Africa in the 1990s and early 2000s; most left family members behind (Abdi 2006; Horst 2006). Somali migrants who arrived in the United States before the civil war became an integral part of the professional and semiprofessional service sector that catered to the Somali refugee influx of the 1990s: case workers, teachers, assistant teachers, health care workers, and interpreters. Like other refugees from underdeveloped conflict regions who become wrapped up in an elaborate refugee

I would like to thank Richard Black, Teresa Gowan, Phyllis Moen, Lisa Park, Jennifer Pierce, Rachel Schurman, and Teresa Swartz for their critical comments on earlier drafts of this article. Thanks also to the anonymous reviewers whose comments greatly strengthened the clarity of the arguments. This research was funded through Social Science and Humanities Research Council of Canada grant 752-2005-0622 03 and British Commonwealth Scholarship CACR-2003-166.

[Signs: Journal of Women in Culture and Society 2014, vol. 39, no. 2]

(c) 2013 by The University of Chicago. All rights reserved. 0097-9740/2014/3902-0008\$10.00 
regime (Portes and Rumbaut 2006), most Somalis rely on governmental benefits, including housing, health care, and basic subsistence from federal and state agencies (MDHS 2004, 1). Data from the American Community Survey show that Somalis have the highest poverty rate of any group in the United States, with 51 percent living in poverty, compared to 13 percent of the US population overall (US Census Bureau 2009, 2). The actual poverty rate might be lower than what the census indicates, however, given that many in this community supplement their governmental benefits with selfemployment in areas such as cab driving and babysitting or employment in low-skilled sectors such as factories and janitorial work (Abdi 2006).

For Somali refugees, the role the state plays in poor households in America represents a new experience, one that influences their gender dynamics. Gender relations in Somalia are patriarchal, with an idealized image of men as household heads anchored in Islamic gender prescriptions (Kapteijns $1999,19)$. In the precolonial era, women's work in household and livestock management was instrumental for family survival, but women were excluded from political power (17-18). With increased urbanization in postcolonial Somalia, the majority of women worked in the informal sector to supplement their low-income households; however, this work was often unacknowledged in discussions of household finances (Abdi 2006). Silence on women's economic contributions increased with this community's heightened religiosity since the conflict, with Islamic discourses embedded in the male breadwinner-female homemaker binary gaining more dominance (Abdi 2007). In the United States, Somalis' low human capital initially forced most families to rely on public assistance, an arrangement that clashed with the male breadwinner ideal. Today there remains a widespread perception that public assistance enrollment exposes families to state scrutiny in their dealings with their households (children, wives, etc.; Abdi 2006), a perception that creates distrust of the welfare regime.

This article examines Somali gender processes in the American context and how this group's migration status and contact with social and police services inform gender negotiations. Two questions anchor the article: First, how are new income opportunities in the United States influencing Somalis' normative gender arrangements? I compare men's and women's interpretations of socioeconomic opportunities and challenges, including welfare regimes and employment in low-skilled sectors. Second, research shows that a diminished economic position for men leads to their decreased authority, which can trigger conflict within the family (Kibria 1993, 14142; Foner 1997, 970). How do Somali men and women articulate this conflict? I discuss Somali men's and women's perceptions of gender conflict, violence against women, and divorce. Integrating the welfare regime and 
religious and cultural norms, I underscore Somalis' interpretations of the key factors shaping gender dynamics. My premise is that perceptions, or definitions of situations, have real consequences, and refugee men's and women's interpretations of emerging gender dynamics in their community carry consequences for how they live, the decisions they make, and the gender order that emerges in the new settlement.

\section{Gender, migration, and patriarchy}

Research on gender and migration, along with the more general literature on gender and patriarchy, focuses on how structural and cultural forces inform gender practices in a given context. The dynamics of gendered power relations and the shifts in this relationship over time and space are crucial for understanding gender as a constructed and fluid concept. Gender and migration studies examine how men and women experience migration. ${ }^{1}$ For example, Pierrette Hondagneu-Sotelo's (1994) work on Mexican migrants highlights how all members of the household-fathers, mothers, children, and extended family — enact and practice gender relations. She further illuminates the gendered interests that men and women maintain and how these at times diverge. Nazli Kibria's (1993) study of Vietnamese refugees exposes the gender tensions brought about by migration to an environment where cultural practices differ drastically from those of the home country. She shows how refugee men and women contest certain traditional family relations while reinforcing others. These findings link macrostructural inequities, such as racial and class dynamics, with microstructural gender and generational processes.

A key question in the extant literature revolves around how migration might challenge patriarchal gender arrangements: "The expectation that women's participation in migratory streams will change their position in society is predicated on beliefs that receiving communities offer a wider (and presumably better) set of social opportunities compared to migrant's communities of origin" (Tienda and Booth 1991, 51). Patricia R. Pessar discusses how she toned down her optimism regarding the emancipatory potential of migration for women when she realized that women might forego certain gains as a way to resist a perceived threat from the mainstream community - that is, racism $(1999,589)$. Although the availability of more economic opportunities may permit immigrant women to challenge aspects of patriarchy, a focus on women's empowerment also indi-

\footnotetext{
${ }^{1}$ See Grasmuck and Pessar (1991), Pedraza (1991), Tienda and Booth (1991), Kibria (1993), Hondagneu-Sotelo (1994), Pessar (1999), Mahler and Pessar (2001), and George (2005).
} 
viduates women, portraying them as primarily concerned with their own needs, an individuation rarely true of women in the north or south (Whitehead 1981).

The literature on gender and patriarchy also underscores the material and normative basis of gender hierarchies and how these shape the roles men and women play in a given society (Hess and Ferree 1987a; Tienda and Booth 1991). Patriarchy, a social system of male domination and female oppression (Kandiyoti 1988, 275; Cockburn 1991, 6), is a key ideology underpinning this hierarchy. However, patriarchy is neither timeless nor monolithic but is subject to historical transformations (Kandiyoti 1988, 274-75). Thus, how gender bargains evolve in the shifting contexts of sociopolitical and economic transformations is central to feminist research. ${ }^{2}$

In "Bargaining with Patriarchy," Deniz Kandiyoti cogently argues that women operate within a set of limitations that "exert a powerful influence on the shaping of women's gendered subjectivity and influence the nature of gender ideology in different contexts" $(1988,275)$. This establishes the potential for women to resist gender subordination, to accommodate it, or both. Such a formulation of patriarchy stresses that while men clearly have a vested interest in maintaining gendered hierarchies, women are not passive actors but rather actively partake in both resisting and perpetuating these arrangements. The strategies men and women ultimately use might fuel identity constructions that influence women's and men's position in society (Mernissi 1987; Kandiyoti 1988; Ahmed 1992). Moreover, they might reveal contradictory gender interests that counter the depiction of the household as a site of harmony and cooperation (Whitehead 1981, 92). Kandiyoti's concept of the patriarchal bargain in essence serves to expose discrepancies between gender ideals and gender practices, just as Arlie Hochschild's Second Shift (1989) illustrated the same contradictory gender ideals and practices in the United States.

Race, class, immigration status, and age also inform the way challenges to gender hierarchies are experienced (Glenn 1987, 373-74; Collins 1990, 70 ; McCall 2005, 1782). The possibility of challenging the existing patriarchal gender bargain is magnified during crises, which render its "systematic contradictions" more visible (Kandiyoti 1988, 285-86). Migration itself constitutes a crisis with great repercussions for patriarchy. Kandiyoti's concept of the patriarchal bargain provides a frame that illuminates the complexities of a Muslim refugee community's gender bargains, which are grounded in northeastern Africa but adapted to a postmigration American context.

${ }^{2}$ See Kandiyoti (1988), Boserup (1989), Hochschild (1989), Tienda and Booth (1991), and Kabeer (2000). 
While Somali refugees share experiences of dislocation with other refugees, I argue that their experiences are also unique. Muslims in the West feel alienated and targeted on the bases of their ethnicities and religious beliefs. ${ }^{3}$ The rhetoric of terrorism exacerbates Muslim experiences of racism, Islamaphobia, and social exclusion. Although American Muslims' educational attainment and incomes are comparable to American median levels (Pew Research Center 2007, 2-3), large pockets of Muslim refugees such as Somalis and Iraqis report extreme levels of poverty (US Census Bureau 2009), and this can intensify the stresses of settlement and the gendered dynamics of migration. For example, as Trees Pels describes in a study of Moroccan migrants in the Netherlands, new sociocultural contexts require new adaptation techniques from fathers, who at times resist changes they perceive as eroding their power over their wives and children $(2000,75)$. Naila Kabeer's (2000) analysis of Bengali women's labor integration in London also shows how the Bangladeshi community's sense of alienation and low human capital in a Western setting leads to a stricter adherence to tradition and religion, thereby strengthening patriarchal relations and curtailing women's integration into the host community.

By contrast, Rima Berns McGown's study of Somalis in London and Toronto argues that Somali women's position in the West is ameliorated "in significant part because of their increased religiosity" $(1999,100)$. Yet increased religiosity can also be an indication of disempowerment (Abdi 2007). One study of Somali family dynamics in Minnesota found that refugees' contact with new institutions definitely affects gender dynamics, with both culture and new American institutions informing changes (Boyle and Ali 2009). Elizabeth Boyle and Ahmed Ali rightly conclude that migrant acculturation theories are applicable to refugees as well (50-51). My comparison of Somali men's and women's articulations of gender processes further extends this work by exposing the types of gender bargains that occur in postmigration settings.

Other scholarship on Muslim immigrants rarely integrates men's perspectives (Abdulrahim 1993; Dwyer 2000; De Voe 2002). This translates into an inadequate appreciation of the gendered dynamics of how Muslim men and women experience migration (Husain and O'Brien 2000). In the rest of this article, I analyze Somali men's and women's articulations of how economic challenges and opportunities inform gender power relations. I provide a thorough discussion of new arenas in which family crisis is attributed to interactions with new institutions in the United States, and I describe men's and women's convergent and divergent interpretations

\footnotetext{
${ }^{3}$ See Husain and O’Brien (2000), Volpp (2002), Pew Research Center (2007), Read (2008), and Korteweg and Yurdakul (2009).
} 
of the consequences of these encounters. Finally, I summarize the implications of this case study for gender and migration studies, identifying possible directions for future research.

\section{Research framework}

The Somali conflict that commenced in the late 1980s led to the dispersal of hundreds of thousands to the far corners of the globe. Minnesota has the largest Somali population in the United States, with estimates ranging from twenty thousand to seventy thousand. The Minnesota State Demographic Center, using measurements including the number of children enrolled in public schools, estimates that the number is close to twenty-five thousand (Roningen 2004), while Somali community organizations give estimates as high as seventy thousand. Community organizations may inflate numbers, while the state's methods may underestimate this population, but either way, these numbers demonstrate the significant size of this population.

In this article, I draw from a thirteen-month qualitative study that I conducted with Somalis in Minnesota. Data collection combined ethnography, in-depth interviews, and focus groups. Some 102 individuals participated in the interviews and focus groups: sixty-two in-depth interviews with thirtythree men and twenty-nine women, as well as eight focus groups with forty men and women. While random sampling was not the goal, I sought to maximize diversity in people's experiences of how gender discourses inform or are informed by the migration experience. For example, eighteen people were under thirty, eighteen were over fifty. All were first-generation migrants (adults at the time of their arrival), except for four participants who arrived when they were younger than fifteen years old. Some worked in social services, while others were in service/manufacturing (cab/truck drivers, health care staff, cleaners, and meat plant workers). Interviewees included college students as well as individuals on the Minnesota Family Investment Program (MFIP) or on Social Security Insurance (SSI). Some had come to the United States before the Somali civil war, while others have been in the country for only five years. All interviewees belonged to the Somali ethnic group, the dominant group settled in Minnesota.

Men and women were interviewed separately. I interviewed women in their homes and to a lesser extent in community centers and educational institutions, while interviews with men were all conducted in public spaces. The Somali Muslim cultural etiquette, as well as my own comfort, led to the latter decision. While my being a woman created a certain distance with men, being an educated Somali woman made up for some of that distance. 
I was received as an insider, and this belonging greatly facilitated my access to the community.

The interviews were semistructured, with a basic set of themes and questions, but also open ended to permit some flexibility. I asked men and women about their migration trajectories and their family backgrounds. I inquired about the roles different institutions (social services, the legal system, community and religious organizations) played in gender dynamics and trends in Somali gender relations. Interviews lasted between one and three hours. I conducted, transcribed, and translated all the interviews, which were conducted in Somali or a mix of Somali and English. I also collected rich data by participating in cultural, political, and religious events, including weddings, funerals, religious celebrations, graduation ceremonies, and community meetings.

I also rely on Somali poetry, plays, and proverbs in this analysis. I did not set out to focus on popular culture in this study, but these forms of culture emerged from my interviews. Like sociology, literature "is concerned with man: his psychological makeup, his social behavior, and even his political acts" (Sederberg and Sederberg 1975, 173). The Somali language was only written in 1972. Hence, poetry and songs passed orally down through the generations represent key historical recordings that can contribute to our understanding of Somali society (Kapteijns 1999, 2-3).

\section{Gendered migration experiences}

Shifting material conditions affect people's normative gender arrangements. Men often construe challenges to their breadwinner roles as challenges to patriarchy, a significant institution in understanding the relationship between social change and gender inequality (Tienda and Booth 1991). Any perceived threat to the gender order (patriarchy) leads to a counterdiscourse aiming to bring the pendulum back to its "rightful" place. When interviewed, one man in his late sixties recited a poem attributed to an unknown male poet that illustrates the significant role structural conditions play in gender constructions. The poem, popular circa the 1950s, comments on the ways the advent of urbanization and capitalism in colonial Somalia supposedly transformed women's culturally sanctioned behavior:

Oh this is a new age for women

There was a time when a destitute man had a chance with them

If he beat her when she was burdened with a child

She did not dare reveal what her husband had done

She tolerated hardship and hunger 
And now no man dares visit her unless he is wearing a suit

Their arrogance, aggressiveness, and poise

When they are walking around in the market

Their grace in walk and quality of dress

Their arrogance, aggressiveness, and poise

You would think that the women of this age had no vaginas ${ }^{4}$

The poem stresses how Somali women in urban settings have replaced their renowned tolerance of hardship in nomadic life with overt challenges to tradition. Their arrogance and disregard for gender hierarchy is contrasted with the good old times when they deferred to men in all circumstances. The poet explicitly designates women's genitalia as the part of their body that encapsulates their inferior position. Urbanized women's lack of deference to men and their declining tolerance of hardship is equated with women's loss of the essence that made them women in the first place, what made them subordinate to men, their genitalia. As detailed in the next section, Somali men perceive the new American context as destabilizing gender dynamics in ways comparable to those brought about by capitalism and urbanization in Somalia.

\section{Men and migration: Rapid social changes and threatened masculinities}

Somali men in this study warn of women's increased transgressions, or kibir, after migration to a Western metropolis. They demonize publicly provided welfare support as the primary culprit for these transgressions. Many predict that the financial opportunities women access in the new settlement and the wide availability of other institutional support such as courts and police services will lead to the demise of the Somali family in America. Despite strong evidence that women contributed to family incomes in Somalia and have continued to play significant roles in family survival since the collapse of the Somali state (Kapteijns 1995, 256-57; Abdi 2006, 131), men portray the family formation of the breadwinner husband and the dependent wife - which is difficult to uphold in the United States, as illustrated by the extremely high poverty rates in this community (US Census Bureau $2009,2)$ - as an ideal. Rarely do men discuss the disjuncture between this ideal and the low socioeconomic position of the average Somali man in the

${ }^{4}$ In Somali, the poem reads: "Saaxiibayaalow haween saacad bow timide / Jeer hore sabool ari yar baa saami ku lahaaye / Iyadoo sidaaloon haduu siiqo kala daalo / Saygeeda uma quuri jirin saattanuu falaye / Saxariirta iyo gaajadana wow samir lahaayeene / Eegana salaan uguma tago suut nimaan qabine / Sarrax taaga iyo aabiga iyo socod wanaagooda / Suuqiyo markay marahayaan saylada iyo toonka / Sin dhaqaajiskoodiyo dharkiyo suufka laga buuxshay / Sarax taaga iyo aabiga iyo socod wanaagooda / Inaan siil ku ool baad hablaha sabanka moodaaye.” 
United States. Instead of discussing the barriers to economic autonomy for the Somali family, men focus on factors they define as problematic for gender harmony: the role of state institutions in family income provisions and the absence of structures and norms sanctioning Somali gender ideology.

Somali men depict conditions in the United States as castrating (xiniinyo bixis). They describe an erosion of the cultural and material bases of their authority and, hence, a menace to their gender ideals. One recurring argument illustrating this anxiety is that women's access to independent incomes through government programs undermines men's religiously sanctioned position as household leaders. The following excerpts exemplify this argument: "The person with the highest share of a company is the CEO. If we say each has an equal share, no one will rule. What will that lead to? Chaos! People are depending on a third party. If there is some outside source of income, then there is no respect between the couple. If you are fed and provided for, then your attachment and respect to each other diminishes. The man is told 'you don't provide for this family, so don't be arrogant" " (Mursal, thirty-five-year-old married man). "If the family consists of independent entities, then this creates a problem. It has two rivals. It is a state with two presidents, instead of a president and a vice president. The women were vice presidents back home; here, a new culture is emerging" (Guled, twenty-six-year-old single man).

The fact that Somali women independently manage and earn their own incomes, and that public assistance checks are issued in women's names, emerges as a key concern for men, who feel dislocated by state welfare institutions. I heard many accounts of how horrified Somali men became once they learned of American social services' practice of putting women's names in families' welfare files. Hence, Somali men's underemployment or unemployment, exacerbated by the significant financial solicitations from families stuck in conflict-ridden Somalia, leads to their inability to support their families with their wages alone and consequently triggers a sense of disempowerment. Their core sense of male identity as family providers is shaken by their migrant status and the welfare and labor market regimes in their new settlement. Thus, like other men clustered in low-income jobs in which authority is minimal and wages fail to meet their families' needs (Glenn 1987 , 371), Somali men insist on women's deference, even as the material basis that previously might have guaranteed this evaporated with migration.

Surprisingly, age is not a factor in how Somali men articulate this perceived emasculation in America. Guled, the twenty-six-year-old university student cited above who came to the United States during his late teens, is

\footnotetext{
${ }^{5}$ All the names used in this article are pseudonyms.
} 
a case in point. This might be an indication that young Somali men in America are still socialized into traditional gender norms. This conclusion is supported by my observation that the majority of young Somali college students I met only interacted and remained in cliques with other Somalis and, thus, have limited hands-on exposure to mainstream gender norms. Men in their fifties, sixties, or seventies, who mostly collect MFIP or SSI and rarely work, also articulate concerns about disempowered Somali men. The elders in this study are all married, with a few having other wives in Africa. One focus group participant in his sixties who is on SSI provides a striking example of how gender dynamics emerging from contact with new institutions create tensions within the household. His case further illustrates the challenges Somali men confront in upholding breadwinner ideals in America. Referring to his own experience with his much younger wife, who works as a cleaner, he stated: "The woman works and earns an income; she puts her income in her pocket saying she will send that to her family; she demands that the man hands over his little income. . . . 'Woman, let us put our money in the same bowl and use it as a family.' But she would say, 'Why are you interfering with mine? My income has nothing to do with you! You are the man, and you should provide for us.' So she puts hers on the side and shares yours with you" (Ibrahim, sixty-sevenyear-old married man). Ibrahim presented his dilemma to a Friday prayers congregation at the mosque, asking religious leaders whether it is his Islamic duty to provide for his wife when she is making more money than he and she herself is not fulfilling her "duties" as a Muslim wife by staying at home. This man insists that his situation is indicative of the unprecedented power women have gained in America. What is distinctive about this case is that Ibrahim's wife turned the tables on him by using the breadwinner rhetoric and challenging him to fulfill his Islamic duty as a provider, a role that most Somali men cannot uphold in America and that, in fact, they did not always uphold in Somalia (Abdi 2006). This woman's strategy represents a gender bargain whereby she exploits Somali and Islamic patriarchal ideals of men as providers to rationalize her full control of her earnings.

Women's desire to use their incomes to support their own extended families (often dispersed in Africa as refugees) also testifies to the competing economic imperatives these men and women navigate. Each has obligations to families left behind, and remittances account for a substantial percent of Somali families' incomes (Abdi 2006; Horst 2006). In the US context, however, Somali men who are able to cover all their families' needs are the exception. Consequently, women combine multiple sources of income to meet their personal remittance obligations as well as their house- 
hold's needs in the United States. These households often rely on a combination of welfare, paid work, and donations from charities to meet their multiple competing commitments.

\section{Women: Rapid social change and gendered opportunities?}

Women interviewees focus on the adaptations required to survive in a Western context in which Somalis occupy a marginal socioeconomic position. They point to the need for women to work, to receive welfare benefits, or both in order to ensure family survival, thus challenging the notion that their access to new sources of income is problematic. Instead, they identify men's increasing sense of disempowerment as the concern:

You see male disempowerment, that his opinions no longer count and that he can no longer dictate. Now you will say, "My brother, the truth is that I need to put money on the table." So he has no way out of this. If he says "stay at home," if he says "you cannot go to school," "my brother, I need to go to school; the welfare worker demands this of me; I will lose the health coverage and the little food stamp." So the woman has to go to school, even if he can bring in an income. Men have been disempowered; they are not running things the way they saw fit. (Asha, forty-two-year-old married woman)

Note how public assistance regulations - in this case the requirement that recipients either get a job or go to school-prevent some gendered demands previously acceptable within the Somali culture. Thus, new institutional interventions such as the state welfare regime's provisions of cash income or food stamps to refugees directly affect family and household dynamics. Institutional imperatives inform gender bargains, providing Somali women with spaces of resistance to patriarchy. The previously dominant male breadwinner role is now challenged by women's contributions to family finances with incomes through formal employment, government support, or both. Unlike men, who vilify welfare, Asha illustrates the need for this source of income and its significance for the household. Yet she also supports men's grievances about encounters with new institutions having curtailed their authority. Somali women's interpretations of the new reality in the United States stress the need for women's contributions. Although the necessity for this income is real in the lived experiences of women and men, women interpret it as instrumental, whereas men view it as a symbolic menace. Hence, women in this study embrace patriarchal bargains that resist male restrictions on their economic strategizing, even when men and a minority of women interpret this as undermining male authority in the household. 
Older women's depictions of Somali gender relations are close to those of men, possibly because most women over age fifty-five are either divorced or widowed and thus do not themselves confront issues of income redistribution with men. These women also support the tenet that men are in charge of women and view this as an Islamic precept that should not be contested. By contrast, women in their late teens or early twenties are much more likely to celebrate potential subversion of traditional patterns. Commenting on migration and women's access to new economic resources, one woman said:

I think migration diminished male authority. Men were breadwinners back home, and [here] they still are but not to the same extent. The woman is running beside him and working. Men had all the power at home: "we are moving, we are moving from this house, 'cause I say so." And now if he is intelligent enough, he will consult with his wife, saying "I have this point of view about this house, it is bad in this way, that way, so we have to move out." But back home, he had the power: "We will move from this house and this is final." . . Like an authoritarian parent. (Ayan, twenty-two-year-old single woman)

Younger women also celebrate what they recognize as women's increased influence within household decision making in America. These women came of age in the United States, and their understanding of Somali gender relations is based on their own family's arrangements as well as stories they have heard on this issue. They dwell on how women were wronged by Somali cultural practices. Overall, they perceive migration as having ameliorated women's bargaining position vis-à-vis men. Nevertheless, they are cognizant that gender power struggles are taking place within households in the community, and they discuss cases involving verbal and physical clashes.

\section{Families in crisis?}

A handful of Somali men I interviewed jokingly mentioned that there was a hierarchy of rights granted to individuals in America: women first, children second, pets third, and men last. Kibria reports that Vietnamese refugee men gave her the same account $(1993,108)$. This parable exemplifies migrants' overwhelming perceptions of menace to men's authority after migration. As I discuss above, Somali men's insistence that women are the ones with balls and that men are castrated (xiniinyo bixis) in the American context illustrates this perception. The logic is that Somali masculine women produced Somali effeminate men. Diminished breadwinner roles for men 
and women's enhanced access to independent resources combine to increase men's insecurity in the new settlement. What is at stake in this gender war is masculinity. Before migration, Somali masculinity was intrinsically tied to men's economic roles as well as their religiously assigned position as heads of households. In America, this community's low socioeconomic status and the prominent role of the welfare regime undermines Somali men's masculinity, triggering a panic about Somali women's subversive power. As Andrea Cornwall and Nancy Lindisfarne observe, "masculinity appears as an essence or commodity, which can be measured, possessed, or lost" (1994, 12).

I contend that Qabyo (1998), a popular play and film by the prominent Somali playwright Abdullahi Mohamed Sangub, watched by young and old alike, played a prominent role in spreading the idea that migration has devastated gender prescriptions. This satire depicts a woman refusing her designated position of deferring wife. Having come to America before her domineering husband, having been taught by her welfare caseworker that women have more rights in America, and having picked up basic English skills, this woman exploits these advantages to dictate the terms of the relationship upon her husband's arrival from Africa. She instructs her husband to no longer expect her to serve him and that he is to babysit and change diapers while she socializes. The husband is scandalized by these new developments and lifts his hand to hit her. The woman stops him with, "This is America. I will call 911 if you lay a finger on me!” Most participants in my study referred to this film as illustrative of transformations in gender roles and relations. I now examine articulations of 911, violence against women, and divorce. Like all power relations, gender relations are continuously under negotiation, and this is most discernible at the "points of change" (Hess and Ferree 1987b, 17), such as settling into a new country and coming into contact with new sociocultural institutions.

\section{1: Threatened masculinities or abused system?}

In Somalia, family transitions and conflicts are spheres beyond the purview of the state. Men and women rarely use state bodies to officiate marriages and divorces, duties carried out instead by religious men at home. As marriage is a contract between families rather than individuals, conflict resolution also involves elderly men from the immediate and extended families. Somalis in America continue this tradition of mediation by elders. However, this practice competes with new institutional interventions such as the police, the 911 service, and the courts to resolve family crises. An elderly man in this study who regularly participates in family mediations emphasized that the main concern in family conflict is tied to how the new context dis- 
rupts Somali marital expectations and the respect that husbands and wives owe each other:

The deference that women held for men is now a thing of the past! Nowadays, no woman appreciates the man as her husband! He might share a life with her, he might have children with her, but very few believe that he is responsible for her. ... People have adapted to this country's [America's] culture where there is no respect for hierarchies [kala dambayn ma jirto]. The man and the woman are two people who are equal. He cannot say a word; no one listens to him at all; if someone is heard, it is the woman. Most of the issues we mediate are not over finances, but rather over respect. (Magan, sixty-six-year-old married man)

I asked Magan what concerns women expressed in these mediation sessions: "Nothing logical, nothing! 'This man comes to the home angry; he spends too much time out; when I talk to him, he tells me to shut up' and so forth. And he is saying, 'I am not getting any respect in this house; even if I ask her to get me a cup of tea, she won't do it. I am getting no respect whatsoever. Despite that, I did not fight with her; she is the one who pushed me, telling me to get out." "Somali elderly men often report reified notions of gendered obligations. They interpret women's demands for more equitable relations as defying Islamic prescriptions, and they dismiss these demands as irrational. The men in this study, who are clearly biased against women, overwhelmingly support the continuation of traditional conflict resolution. Men insist that women resorting to 911 (as one male interviewee put it, "a system set up for people who are non-Muslims") has great ramifications for the community. This system is viewed as hostile to Muslims and is distrusted as intending to break up families. By contrast, Islamic and Somali cultural prescriptions of conflict resolution are perceived as striving for family unity.

Some men acknowledge that there are times when police involvement in family conflict might be necessary. They view severe beating as a legitimate basis for calling 911, for example, whereas arguments or "minor" physical infringements are not seen as justifying police intervention. Interviewees all express apprehension regarding the serious consequences of legal action against alleged abusers, who will then confront incarceration and possibly deportation. Many maintain that conflict in a relationship is inevitable and illustrate this with the Somali proverb "Carrab iyo ilko ayaa iskaga dhow wax walba, ayaguna way is qaniinaan" (Nothing is closer than teeth and tongue, and these bite each other). Hence, those individuals re- 
sorting to state institutions to resolve their conflict are condemned by the majority of men, who nevertheless insist that they do not condone violence against women but rather abhor institutional interventions, which they describe as a threat to an already marginalized Muslim community.

A few men deem police involvement in any type of domestic abuse as an extreme solution to a problem that should always be mediated between families. The consequences of a criminal record for men are thus prioritized over the consequences of violence for women. For instance, a third-year university student and community activist detailed how his best friend once brutally beat his wife. When asked how this case ended, he replied: "The woman was good. We went to see her and we resolved the problem. ... He beat her when she was wearing a light dress [dirac khafiifa]. She was reasonable! We advised her [waan u caqli celinay]. She did not call 911 on him and she did not kick him out. And we talked to him and told him not to repeat this" (Omar, twenty-six-year-old single man). Regardless of age, the men in my study distrusted state intervention and placed family union above all in cases of violence against women. Omar, who came to the United States in his late teens, indicates that it never occurred to him to call 911 or inform the police about the case. He in fact praises the woman for not taking legal action against her abusive husband and describes her silence as protecting the Somali community from undesirable institutional interference. This stance characterizes the vilification that women who call 911 experience. These women are regarded as violating gendered norms. Two friends, including Omar, came to this woman's home after the violence, and they conspired to hide it from the police, who had been called by neighbors.

Contrary to allegations that Somali women misuse 911 services, I know of two other serious cases of violence in which the police never got involved. The small number of research participants who personally knew a woman who had used this service suggests possible exaggeration as to the numbers of women using or abusing 911. Men nevertheless overwhelmingly claim that 911 misuse represents a community crisis. I argue that this points to Somali male insecurity in the American context, in which their incomes are stretched to support immediate and extended kin and rarely meet their families' needs, diminishing their authority within their households. Moreover, their status within the larger community is also undermined by their religious and socioeconomic marginalization. Somali women's use of 911 to punish men, as epitomized in Qabyo, has become an indisputable "truth," regardless of how often it actually occurs. I contend that men perpetuate this stereotype to control women, thus reinforcing a more traditional gender arrangement. 


\section{1: Embraced opportunities or transgressions?}

Unlike men's and women's divergent viewpoints on the impact of new economic opportunities on gender dynamics, most Somali women interviewees concur with men that any type of police intervention in the community should be condemned. As one woman in her midthirties put it:

I think Somali women misunderstood 911. They use it as a weapon against their husbands. It is like "you are not doing this or that for me, get out of my home, and if you don't, I will call the police." Come on! We have a culture; we have other ways we can resolve our problems, whether it is family or relatives mediating. I am personally against 911 . . . I don't think I would ever consider using it. It is not a good thing. . . . You have deviated from your culture and religion! You are using a system that non-Muslims have created for themselves, you know. And the problem for your family! Because this is your husband after all, and you will take him back. (Hibak, thirty-four-year-old divorced woman)

Hibak underscores the Somali distrust of American institutions by stressing her community's distinct cultural and Islamic heritage, which she believes should anchor family conflict resolution. She also alleges that some women abuse the system and create problems for the community.

A Somali counselor who works with women in abusive relationships refutes this assertion, reporting that women's contact with police is often a last resort to enduring violence. I argue that abused women's unwillingness to seek assistance is closely related to the rhetoric of women abusing 911 services. This rhetoric is so pervasive and so stigmatizing that women hesitate to involve outsiders in their family issues in an environment where the whole community feels vulnerable. Apprehension about the potential incarceration and deportation of those reported to the authorities as well as the stigma around getting non-Somalis and non-Muslims involved in family affairs are central to women's reluctance to use this service. For example, even this counselor insists that it is not in these families' interest to charge these men and argues that it is better for them to resolve their problems through mediation: "When there is a conflict between the couple, our aim in this program is that these [couples] live in peace in this foreign country. It does not benefit anyone if the person is deported. I as an advocate advise women that it is not in their best interest. If he leaves you alone, it is not in your interest to pursue the case and to have him deported. Maybe some of these [couples] have children. Maybe they could not get along because of personality differences, but he might be useful 
when the children have problems. You never know" (Sahra, thirty-nine-yearold married woman, counselor).

Sahra, in essence, shares the community's apprehension around the prospect of women taking legal action against abusive husbands. Moreover, the absence of kinswomen, who were instrumental in child rearing in Somalia, and the general absence of family support in a setting some Somalis view as alien and hostile deters women from pressing charges. Migration has essentially shifted women's reliance on kinswomen for emotional and physical assistance with child care and housework to a reliance on their husbands alone. Sahra's rationale that "he might be useful when the children have problems" testifies to this consequence of migration. Sahra also recounts the experiences of a family with five children in which the husband beat the wife and the children called the police. This woman eventually dropped the charges, and Sahra praised her for "understanding the system." Fear of isolation and stigma, along with advice from the counselor and elders, were significant in this woman's reluctance to pursue the case. And the consequences of deviating from the norm in an environment viewed as hostile to Muslims far outweigh any returns from an uncertain legal battle with an abusive partner. In certain instances, then, Somali women are obligated to promote traditional conflict resolution in family conflict, a gender bargain that reinforces their subordination to men.

While the constant rhetoric of women misusing 911 depicts an environment where family conflict is pervasive, I documented five women in abusive relationships, and I would argue that the portrayal of 911 usage in Qabyo leads to an erroneous perception of police omnipresence in Somali households. Some women might be reluctant to divulge such personal and problematic experiences to a stranger, especially given the fact that widespread condemnations of 911 have rendered all contact with police as suspect and potentially involving false allegations. However, although I did not interview police personnel, Boyle and Ali, who interviewed a police lieutenant on this question, report that domestic abuse rates are no different for this community than any other $(2009,63)$. The Somali caseworker who supports women in abusive relationships also indicates that false allegations of abuse are rare, being aware of only seven cases of false abuse allegations between 1998 and 2004.

Repeated accounts of Somali women calling 911 on their husbands, of men being arrested or deported, and of single mothers struggling to raise children and losing control of boys in a foreign context all serve as cautionary tales for women. These tales appear to succeed in discouraging some women from even considering seeking help since the stigma and the 
loss of respect within the community can be immense. Somali women in America are thus put in "the unenviable position of having to choose between rights and respect" (Hijab 1998, 46). Choosing rights by seeking legal protection against partners compromises women's standing in the community since they confront stigma and alienation, and as a result, a loss of respect.

In contrast to men, who benefit more from patriarchal ideals, age is important in how Somali women view violence against women. Unlike their older counterparts, women in their late teens and early twenties generally caution against condemning women who seek support against abuse. They highlight why 911 should not be problematic since it is a useful service for women confronting violence. They praise women for no longer tolerating abuse, which they view as un-Islamic. Two young women recited the prophet Muhammad's practices (hadiths), to underscore his kindness to his wives and how Muslim men should strive to imitate him. Note how these women also use Islam but reach different conclusions in their attitudes toward domestic violence. They predict that violence against women will decline as more women learn about their rights in the United States and as abusive men taste the consequences of their behavior.

\section{Divorce: Alternative framings?}

An overwhelming majority of research participants report that divorce rates have skyrocketed among Somalis in America. Many attribute this increase to women's deviation from their religious and traditional obligations by getting police involved in family disputes. Elderly men further maintain that it is women who are more insistent on obtaining divorce in mediation sessions. These elders argue that women's access to public assistance in America leads to increasing disregard for the institution of marriage. Women's rush to divorce in America is contrasted with the shame attached to this in Somalia. Research participants mention an increasing number of single mothers within the Somali American community as proof of soaring divorce rates.

The fact that some interviewees had had one or more divorces before migration, however, contradicts the statement that divorce is a rare, stigmatizing phenomenon in Somalia. Of the six women interviewees over age fifty-five, three had been divorced twice, two once each, and only one has never been divorced. One elderly woman who is divorced pointed out how her now-deceased mother and both her son and daughter have previously divorced. To the question of whether divorce is stigmatizing in Somalia, another elderly woman stated: "No, not in our culture! The person was free! ... We went our different ways. He came back later wanting to get back together, but I refused. I said there is no place for me in your life. I left 
him after he took a second wife. Alhamdu Lillah [thanks to Allah]. His family actually raised the kids with me, especially his mom. They took some and I continued working" (Suuban, sixty-eight-year-old divorced woman). A common Somali proverb used by a few elderly women states, "it is better to divorce thirty times than to live in misery with one man" (silic ku nool sodon guursataa dhaanta), and this further contradicts the notion that divorce is stigmatizing in Somalia. And divorce is even more common for older men, some of whom have had three or more divorces. Five of the seven men over fifty-five were in fact in polygamous relationships, and three had been married to up to four women at any given time. Although each has only one wife in Minnesota, they left other wives and ex-wives back in Somalia and neighboring countries. Of the forty-five interviewees over age thirty, nineteen have divorced at least once.

The divorce crisis portrayed by Somalis in America is a reflection of perceived threat to culturally and normatively constituted masculinity rather than an increase in divorce rates. In fact, economic and religious marginality, loss of kinswomen for child-rearing support, and community pressures all discourage women from seeking divorce. I argue that divorce for women seems more costly and more stigmatizing in the United States than it was in Somalia since the ramifications for women with children are immense. I interviewed a few women in very difficult relationships who still opted not to seek divorce. For instance, Farhiya, who accused her husband of psychological and financial neglect of her and her five children, reported that she would never ask for a divorce. She stated, "If he leaves, it has to be on his own volition. I don't want to be the initiator of the divorce." And a group of women discussing the situation of a woman who has stuck with her abusive husband praised this woman for knowing her priorities, as she does not have any kin in America and her husband assists her with the groceries and with the children. Finally, a woman in her thirties who is now divorced discussed how her family conflict dragged on for four years. As she put it, "I could not disobey my mother and the elders in my family. They said to me 'our daughter, we will give you our blessings; you can choose our blessings or our curses [habaar am duca dooro]. We love you and we do not want you to destroy your family as neither of you will benefit from that and you will suffer the consequences'" (Hodan, thirty-four-year-old divorced woman). This woman, who had three children during this prolonged mediation attempt, finally got her divorce in 2003 . However, it was her husband who walked out, sending her the divorce letter by mail.

These cases contradict the notion of women deviating from traditional gender practices since most in fact maintain deference to their elders and to Somali normative gender ideology, even to their own detriment. The 
stigma of being a divorced single mother, which was discussed throughout my interviews, informs these women's decisions. Most men, and some women, portray single mothers as a desperate lot who could easily be lured into illicit sexual relations or into marriage to already married men: "She [a single mother] will say to herself, 'Since I cannot find a good husband, I am thinking of sharing this one with this woman.' Because there are not many good single men around, men sway more power over women and end up with more choices, saying, 'If I leave one today, I will find another one; I will find a single mother next door who will pamper me like a baby and who will not be demanding" " (Najma, forty-seven-year-old married woman).

It is not only that single mothers' status and bargaining power diminishes vis-à-vis potential suitors but also that their reputation remains suspect once divorced. Consistent with what has been depicted in Qabyo, a few of my interviewees alluded to single mothers who consort with men outside the context of marriage, thus leading immoral lives. Although no one could name any such women, the rhetoric around "loose" divorced women, who gain autonomy and are freed from family scrutiny in America, is part and parcel of the male gender strategy to curtail women's status in the gender bargain. The extended family, which acted as a control mechanism for women in Somalia, is mostly missing in the American context (Boyle and Ali 2009, 72). Thus, the practical challenges of being a single parent and the stigma of being regarded as morally loose render divorce costly for women. Related to this is the power asymmetry between men and women in obtaining divorces. Men are able to repudiate women without serious consequences, a prospect that many women in Muslim societies confront (Mernissi 1987). In contrast, women are at the mercy of men in obtaining a divorce, even when they have strong grounds. Elders, religious and secular community organizations, and insecurities in the American context all influence women's accommodation of gender bargains that perpetuate their subordination.

\section{Conclusion}

Feminist scholars increasingly embrace intersectionality as a way of locating women's and men's lives within the multilayered social structures in which they are embedded (McCall 2005). This ethnography of Somali migration experiences points to the complexity of gender change in the context of the intersectionality of gender, migration, religion, and the welfare state. Understanding gender dynamics among Muslim refugees in America thus expands our understanding of the gendered nature of migration. 
The analysis underscores how refugees' contact with new institutions in the place of settlement triggers patriarchal bargains. Although it facilitates settlement, the American regime of financial support provision for newcomers also emerges as a significant arena that produces competing gendered narratives. Somali men articulate their goal of preserving a religiously and traditionally buttressed gender ideology while vilifying any deviation from the gender order. Consistent with findings in earlier scholarship, however, it is not only men who support and benefit from this ideology. Both men and women participate in the constructions and perpetuations of patriarchy. I find that women resist patriarchal ideologies that locate them in subordinate positions within the household by seeking independent incomes, but they also collude in the maintenance of gender inequality by criticizing other women's use of 911 services, for example. In these cases, women's gender interests become subordinated to those of the community, which feels vulnerable in the American context. The absence of other female kin, who previously provided women with significant emotional and physical support with reproductive responsibilities, also leads to more reliance on husbands for these duties. This in part explains why women support male critiques of institutional interferences in family relations, even though this produces gender bargains that subordinate them.

The findings of this study also support the argument that women's consciousness about their subordination is heightened with migration. This heightened awareness might not always translate into real changes within the household, however. The dynamic responses to structural and individual opportunities and constraints show Somali women's agency while underscoring their ambivalence regarding some of the options they confront: a sense of isolation and ostracism from within when they defy the normative gender order of their community or a sense of isolation, racism, and religious discrimination against their community from without. These findings further demonstrate the complexity and the contingent nature of gender negotiations, which defy the empowerment-disempowerment binary.

Somali gender processes in America also illustrate how a particular patriarchal arrangement transposed to a transnational setting can trigger identity constructions. While new opportunities for women potentially transform this bargain to a more equitable one, men's discourses-legitimated by the greater Somali community leadership and by elders - exploit reified religious prescriptions and strive for more stringent gender relations. Perceived and real threats against the new community, which are cemented in slapstick theater pieces like Qabyo, still help men to reify patriarchal ideologies and to insulate the community from mainstream gender norms. In fact, such cautionary tales not only restrict new challenges to the gender or- 
der, but they also attempt to alter some freedoms that women exercised before migration, as illustrated by discussions on divorce. Divorces are now mostly attributed to the institutional opportunities allegedly favoring women that are seen to threaten the Somali family. Theater, then, even comic theater like Qabyo, serves as a mechanism of control to balance institutional influences in families after migration. Furthermore, in a context of increasing religiosity in the Somali community in and outside of Somalia (Abdi 2007), perceived hostile attitudes toward Muslims by the host society provide a justification for men's reification of patriarchal gender ideals. Thus, both religious beliefs and experiences of reception influence migrants' gender bargains, curtailing women's options to resist their subordination in America.

Finally, the recent nature of Somali settlement in America means that what is captured in this article is just a glimpse of the fast-paced changes inherent in migration. Future research can enlighten us as to how the Somali community is accommodating the demands of the second generation. Furthermore, Somali men themselves may also be changing, albeit reluctantly. Although the views of men in this study might cause pessimism about equitable gender relations, it is arguable that this research is capturing gender at one point in the process of a community's adjustment to a new environment. It is not surprising, therefore, that in the context of seemingly confusing and fast-paced transformations of identity constructions and reconstructions, interpretations of gender are sometimes contradictory and vastly different for men as compared with women. Future research can further unpack how the Somali gendered articulations presented in this article are evolving with the community's longer stay in America.

Department of Sociology

University of Minnesota

and

Department of Sociology

University of Pretoria

\section{References}

Abdi, Cawo Mohamed. 2006. "Diasporic Lives and Threatened Identities: Gender Struggles of Somalis in America." PhD dissertation, University of Sussex.

- 2007. "Convergence of Civil War and the Religious Right: Reimagining Somali Women." Signs: Journal of Women in Culture and Society 33(1):183-207.

Abdulrahim, Dima. 1993. "Defining Gender in a Second Exile: Palestinian Women in West Berlin." In Migrant Women: Crossing Boundaries and Changing Identities, ed. Gina Buijs, 55-82. Oxford: Berg. 
Ahmed, Leila. 1992. Women and Gender in Islam: Historical Roots of a Modern Debate. New Haven, CT: Yale University Press.

Berns McGown, Rima. 1999. Muslims in the Diaspora: The Somali Communities of London and Toronto. Toronto: University of Toronto Press.

Boserup, Ester. 1989. Woman's Role in Economic Development. London: Earthscan.

Boyle, Elizabeth Heger, and Ahmed Ali. 2009. "Culture, Structure, and the Refugee Experience in Somali Immigrant Family Transformation." International Migration 48(1):47-79.

Cockburn, Cynthia. 1991. In the Way of Women: Men's Resistance to Sex Equality in Organizations. Ithaca, NY: ILR Press.

Collins, Patricia Hill. 1990. Black Feminist Thought: Knowledge, Consciousness, and the Politics of Empowerment. Boston: Unwin Hyman.

Cornwall, Andrea, and Nancy Lindisfarne. 1994. "Gender, Power and Anthropology." In Dislocating Masculinity: Comparative Ethnographies, 11-47. London: Routledge.

De Voe, Pamela A. 2002. "Symbolic Action: Religion's Role in the Changing Environment of Young Somali Women." Journal of Refugee Studies 15(2):234-46.

Dwyer, Claire. 2000. "Negotiating Diasporic Identities: Young British South Asian Muslim Women.” Women's Studies International Forum 23(4):475-86.

Foner, Nancy. 1997. "The Immigrant Family: Cultural Legacies and Cultural Changes." International Migration Review 31(4):961-74.

George, Sheba Mariam. 2005. When Women Come First: Gender and Class in Transnational Migration. Berkeley: University of California Press.

Glenn, Evelyn Nakano. 1987. "Gender and the Family." In Hess and Ferree 1987a, $348-80$.

Grasmuck, Sheri, and Patricia R. Pessar. 1991. Between Two Islands: Dominican International Migration. Berkeley: University of California Press.

Hess, Beth B., and Myra Marx Ferree, eds. 1987a. Analyzing Gender: A Handbook of Social Science Research. London: Sage.

- 1987b. "Introduction." In Hess and Ferree 1987a, 9-30.

Hijab, Nadia. 1998. "Islam, Social Change, and the Reality of Arab Women's Lives." In Islam, Gender and Social Change, ed. Yvonne Yazbeck Haddad and John L. Espsito, 40-54. Oxford: Oxford University Press.

Hochschild, Arlie. 1989. The Second Shift: Working Parents and the Revolution at Home. New York: Viking.

Hondagneu-Sotelo, Pierrette. 1994. Gendered Transitions: Mexican Experiences of Immigration. Berkeley: University of California Press.

Horst, Cindy. 2006. "Connected Lives: Somalis in Minneapolis, Family Responsibilities and the Migration Dreams of Relatives.” Research Paper no. 124, New Issues in Refugee Research, UN High Commissioner for Refugees, Geneva. http://www.unhcr.org/44b7b6912.pdf.

Husain, Fatima, and Margaret O’Brien. 2000. "Muslim Communities in Europe: Reconstruction and Transformation." Current Sociology 48(4):1-13. 
Kabeer, Naila. 2000. The Power to Choose: Bangladeshi Women and Labour Market Decisions in London and Dhaka. London: Verso.

$\rightarrow$ Kandiyoti, Deniz. 1988. "Bargaining with Patriarchy." Gender and Society 2(3): 274-90.

Kapteijns, Lidwien. 1995. "Gender Relations and the Transformation of the Northern Somali Pastoral Tradition." International Journal of African Historical Studies 28(2):241-59.

1999. Women's Voices in a Man's World: Women and the Pastoral Tradition in Northern Somali Orature, c. 1899-1980. Portsmouth, NH: Heinemann.

Kibria, Nazli. 1993. Family Tightrope: The Changing Lives of Vietnamese Americans. Princeton, NJ: Princeton University Press.

Korteweg, Anna, and Gökçe Yurdakul. 2009. "Islam, Gender, and Immigrant Integration: Boundary Drawing in Discourses on Honour Killing in the Netherlands and Germany." Ethnic and Racial Studies 32(2):218-38.

Mahler, Sarah J., and Patricia R. Pessar. 2001. "Gendered Geographies of Power: Analyzing Gender across Transnational Spaces." Identities 7(4):441-59.

McCall, Leslie. 2005. "The Complexity of Intersectionality." Signs 30(3):1771-1800.

MDHS (Minnesota Department of Human Services). 2004. "Characteristics of December 2003 Minnesota Family Investment Program Cases and Eligible Adults by Racial/Ethnic Groups and Subgroups." Report, REIS no. 9, MDHS, Minneapolis. http://edocs.dhs.state.mn.us/lfserver/Legacy/DHS-4262I-ENG.

Mernissi, Fatima. 1987. Beyond the Veil: Male-Female Dynamics in Modern Muslim Society. Bloomington: Indiana University Press.

$\rightarrow$ Pedraza, Silvia. 1991. "Women and Migration: The Social Consequences of Gender." Annual Review of Sociology 17:303-25.

$\rightarrow$ Pels, Trees. 2000. "Muslim Families from Morocco in the Netherlands: Gender Dynamics and Fathers' Roles in a Context of Change." Current Sociology 48(4): 75-93.

Pessar, Patricia R. 1999. "Engendering Migration Studies: The Case of New Immigrants in the United States." American Behavioral Scientist 42(4):577-600.

Pew Research Center. 2007. "Muslim Americans: Middle Class and Mostly Mainstream." Report, Pew Research Center, Washington, DC. http://pewresearch .org/assets/pdf/muslim-americans.pdf.

Portes, Alejandro, and Rubén G. Rumbaut. 2006. Immigrant America: A Portrait. Berkeley: University of California Press.

Qabyo. 1998. Directed and produced by Abdullahi Mohamed Sangub.

Read, Jen'nan Ghazal. 2008. "Muslims in America." Contexts 7(4):37-41.

Roningen, Barbara. 2004. "Minnesota's African Population.” Paper presented at the Africans in the Diaspora Conference, University of Minnesota, June 18.

Sederberg, Peter C., and Nancy B. Sederberg. 1975. "Transmitting the Nontransmissible: The Function of Literature in the Pursuit of Social Knowledge." Philosophy and Phenomenological Research 36(2):173-96.

Tienda, Marta, and Karen Booth. 1991. "Gender, Migration and Social Change." International Sociology 6(1):51-72. 
US Census Bureau. 2009. "Census Bureau Data Show Characteristics of the U.S. Foreign-Born Population.” Press release, US Census Bureau, Washington, DC, February 19. http://www.census.gov/newsroom/releases/archives/american _community_survey_acs/cb09-cn01.html.

Volpp, Leti. 2002. "The Citizen and the Terrorist." UCLA Law Review 49(5): $1575-1600$.

Whitehead, Ann. 1981. “'I Am Hungry, Mum': The Politics of Domestic Budgeting." In Of Marriage and the Market: Women's Subordination in International Perspective, ed. Kate Young, Carol Wolkowitz, and Roslyn McCullagh, 88-111. London: CSE. 